\title{
Evolution of child labor rate in Brazilian states: policy limits and contradictions *
}

\author{
Temidayo James Aransiola ** \\ Marcelo Justus ${ }^{* * *}$
}

\begin{abstract}
This study descriptively explores the evolution of child labor rates in Brazilian states from 2000 to 2014 and indicates specific limits and contradictions of governmental measures adopted for its reduction. On one hand, we examine the coverage of the Bolsa Família conditional cash transfer (PBF), which is a transversal program to reduce poverty. On the other hand, we examine the design of Labor Inspections with a focus on child labor. For this, we used data from the National Household Sample Survey, the Ministry of Social Development and the Ministry of Labor and Employment. Our analysis showed that the expressive reduction of the child labor rate in Brazil was driven, in particular, by the rural areas of the North and Northeast regions. However, the agricultural sector is still the major employer of child labor. We also found that the distribution of governmental countermeasures are contradictory as to the rate of child labor in the states. Inspection activities are shorthanded in fighting child labor in domestic work and family agriculture as a result of the constitutional apparatus of the inviolability of homes. The PBF conditional cash transfer is also limited in tackling child labor given that poverty level determines eligibility.
\end{abstract}

Keywords: Bolsa Família; Labor Inspection; Limit; Contradiction.

\section{Resumo}

\section{Evolução dos níveis de trabalho infantil nos estados brasileiros: limites e contradições das políticas}

Este estudo explora de forma descritiva a evolução dos níveis de trabalho infantil nos estados brasileiros, do ano de 2000 até 2014, e indica limites e contradições específicos das medidas governamentais adotadas para tentar reduzílos. Por um lado, examinamos a abrangência do Programa Bolsa Família (PBF), que é um programa transversal para reduzir a pobreza. Por outro, examinamos o padrão de Inspeção do Trabalho, com foco no trabalho infantil. Para isto, utilizamos dados da Pesquisa Nacional por Amostra de Domicílios, do Ministério do Desenvolvimento Social e do Ministério do Trabalho e Emprego. Nossa análise mostrou que uma redução expressiva dos níveis de trabalho infantil no Brasil foi conduzida, especialmente, pelas áreas rurais nas regiões Norte de Nordeste. Porém, o setor agrícola ainda é o que tem maiores níveis de trabalho infantil. Também observamos que ambas contramedidas governamentais possuem distribuição contraditória em relação aos níveis de trabalho infantil nos estados. As atividades de inspeção não são suficientes para combater o trabalho infantil em atividades domesticas e de agricultura familiar, sendo este um resultado do preceito constitucional de inviolabilidade do domicílio. A transferência monetária condicional denominada Programa Bolsa Família (PBF) também é limitada no combate ao trabalho infantil, devido aos níveis de pobreza exigidos para que as pessoas possam ter acesso a ele.

Palavras-chave: Bolsa Família; Inspeções do Trabalho; Limite; Contradição.

JEL J08, J46, J48.

* Article received on June 29, 2017 and approved on October 11, 2019. We would like to thank Fapesp (The São Paulo Research Foundation) for financial support to develop the master's thesis that contains this research (Process number 2015/21410$8)$.

${ }^{* *}$ Ph.D student at the Institute of Economics, University of Campinas, Campinas, SP, Brazil. E-mail: 162937@ unicamp.br.

**** Profesor at the Institute of Economics, University of Campinas, Campinas, SP, Brazil. E-mail: mjustus@unicamp.br. 


\section{Introduction}

Brazil has recently been internationally cited as one of the successful countries in the combat of child labor. This is due to the expressive reduction observed since the beginning of the 21st century. However, Conaeti (2011), and Rosado and Luciana (2014) pointed to a fall in the rate of decline of child labor in specific activities such as family agriculture and urban informal services. According to these studies, such a trend is due to the limits of governmental policies to reach these activities.

There is widespread literature on Brazil regarding the determinants of child labor. The most cited are family income, family structure, parent's education, level of urbanization and social culture and ideology (Basu, 1999; Kassouf, 2001; Emerson; Souza, 2003; Lopez-Calva, 2003; Guarcello et al., 2007; Kassouf; Justus, 2010, to mention a few). Some studies have also found evidence concerning the consequences of early work on health and future earnings of individuals and, consequently, on the economy as a whole (Baland; Robinson, 2000; Feitosa et al., 2001; Emerson; Souza, 2011; Justus et al., 2015; Aransiola and Justus, 2018). Some focus on the long-run cycle of child labor among generations of the same family (Emerson; Souza, 2003; Aquino et al., 2010). Although no clear consensus has been reached, recent studies have also investigated the impact of governmental countermeasures on child labor in Brazil (Cardoso; Souza, 2004; Ferro et al., 2010; Cacciamali et al., 2010; Araujo et al., 2010; Nascimento; Kassouf, 2016). The observed lack of consensus is the primary motivation for this study.

Conditional cash transfers are the major countermeasures adopted in Brazil against child labor. Among these are the Program for Eradication of Child Labor (PETI) ${ }^{1}$ and the Bolsa Familia Program (PBF), both managed by the Ministry of Social Development (MDS). The difference between both programs is that the former only attends to families above the poverty line and is, thus, exclusively focused on families with child laborers. However, the latter attends to all poor and extremely poor families, making it a cross-cutting and wider program. As for inspection, the only governmental measure adopted to reduce child labor is the "Labor Inspection with a focus on child labor" (henceforth, Labor Inspection) conducted by the Ministry of Labor and Employment (MTE). In this study, we opt to focus on the PBF and Labor Inspection since both are nation-wide governmental measures but differ in the sense that the former is cross-cutting and voluntary, while the latter is focal and involuntary.

In short, the major contribution of this study is to provide a relevant descriptive analysis of the evolution of the prevelance of child labor in Brazilian states and to shed light on some limits and contradictions faced by the PBF and Labor Inspection activities.

In addition to this brief introduction, section 2 describes and contextualizes the governmental countermeasures which we emphasize. In section 3 we present data sources, analyses and discussions. Conclusions are provided in section 4 .

(1) Henceforth, we will use common Brazilian acronyms and abbreviations. 


\section{Countermeasures against child labor}

\subsection{Labor Inspection}

Labor Inspections focusing on child labor were implemented in Brazil as a result of expressively high rates of child labor in the 1980s. Thenceforth, inspections have been managed by the Secretariat of Labor Inspection (SIT), which is part of the Brazilian Ministry of Labor and Employment (MTE).

In practice, inspections are preceded by an annual plan elaborated by the Regional Superintendencies of Labor and Employment (SRTEs) based on SIT guidelines. In this plan, inspections are geographically allocated based on the reported incidences of child labor, prioritizing the worst forms. Subsequently, inspectors engage in preventive actions that involve awareness-creation by publicizing the negative impacts of child labor through lectures, seminars, debates, and campaigns to children, employers, and families. In the following months, inspectors are designated to visit specific businesses or workplaces in urban and rural areas throughout the country (ILO/SIT, 2010).

During these visits, inspectors identify irregularities concerning child labor and report the characteristics of work exercised by children and adolescents. When judged necessary, children and adolescents are withdrawn from work and infraction reports are issued to exploiters, which may lead to fining. To avoid the return to work, children and adolescents are included in social welfare programs. Children (below the age of 14) are enrolled in cash transfer programs conditioned to school attendance and participation in social, educational and healthcare projects. Adolescents (below the age of 15) are enrolled in apprenticeship programs which offer educative and technical training. It is important to note that aside from being a countermeasure focused on child labor, inspections can reach the entire population, provided that child labor is detected, since the withdrawal of children and adolescents from work is involuntary and does not require eligibility compared to conditional cash transfers.

\subsection{Conditional Cash Transfer (CCT)}

The Bolsa Escola and Renda Mínima ${ }^{2}$ were the first CCT programs adopted in Brazil in the mid-1990s. These programs granted financial subsidies to poor parents under the condition of enrolling their children in school. In 1996, the Program for Elimination of Child Labor (PETI) was created to address the high proportion and precarious situation of children in the labor market. According to Soares and Sátyro (2010), the PETI also had the objective of withdrawing children and adolescents between the ages of 7 and 15 from hazardous work and enrolling them in school. The PETI program also required children to participate in extracurricular sport, cultural, artistic and leisure activities in order to prevent time allocation to work.

(2) Schooling Grant and Minimum Income, respectively. 
In 2003, all cash and in-kind transfer programs designed to reduce poverty were combined to form a single nationwide CCT program - the Bolsa Família Program (PBF), which is managed by the Ministry of Social Development (MDS). Participation of families in the PBF is conditioned on the level of family per capita income, whereas to continue in the program, beneficiary families have to meet additional conditions concerning health care and enrollment and attendance of children in school. Therefore, one can interpret that the program seeks to increase the human capital of poor families through education and health, which in turn can yield better income distribution in the long run and also interrupt the poverty cycle.

In 2005, the PETI program was incorporated into the PBF to enhance management and encourage synergy between both programs. Despite critics regarding the amalgamation of these welfare programs, experts affirmed in the report published by Repórter Brasil (2013) that such an action was imminent to optimize public resources, increase coverage and enhance the accessibility of grants by eligible families. In practice, child labor is addressed by one of the conditionalities for participation in the PBF which obligates beneficiary families to withdraw children from work and enroll them in school.

Presently, the PBF attends families with per capita income below the poverty line ${ }^{3}$, prioritizing families with pregnant women or children or adolescents under the age of 17 . Regarding financial values, a fixed amount of $\mathrm{R} \$ 77$ (Brazilian currency) is transferred to extremely poor families irrespective of family structure. In addition, a variable amount between $\mathrm{R} \$ 35$ and $\mathrm{R} \$ 175$ is transferred to poor and extremely poor families depending on the family structure. As observed through the values, the PBF particularly aims to raise vulnerable families above the poverty line. Note that unlike the Labor Inspection policy, participation in the PBF is voluntary and limited to the poor population. To cover such a gap, the PETI program was reconfigured to reach child laborers from families above the poverty line. However, the value transferred is expressively lower than that of the PBF program - R $\$ 25$ per child to families who reside in rural or urban areas with less than 250 thousand inhabitants and $\mathrm{R} \$ 40$ per child to families who reside in urban areas with more than 250 thousand inhabitants. Contrastingly, according to data from the 2014 National Household Sample Survey (PNAD), the average income of child laborers in urban and rural areas was about $\mathrm{R} \$ 363$ and $\mathrm{R} \$ 262$, respectively.

\section{Data and analysis}

\subsection{Sources of data}

Following ILO conventions, the Brazilian Federal Constitution defines child labor as the engagement of children and adolescents between the ages of 5 and 15 in any labor activity,

(3) In 2014 , the poverty and extreme poverty line were set at $\mathrm{R} \$ 154$ ( $\$ 1.90$ per day) and $\mathrm{R} \$ 77$ ( $\$ 0.95$ per day) monthly per capita income, respectively. 
except in the condition of apprenticeship as from the age of $14^{4}$. This is the definition that we use throughout this study.

Data concerning the child labor rate from 2004 to 2014 was obtained by aggregating microdata of the National Household Sample Survey (PNAD) by state. All estimates were computed using the weights or sample expansion factors provided by the IBGE in the data files. Data on the Bolsa Familia Program and Labor Inspection was obtained from the Ministry of Social Development and Ministry of Labor and Employment, respectively. As for the PBF, we make a comparison of data from 2004 to that from 2014, by state. However, for the labor inspection, we compare data from 2007 and 2014 since such a focal inspection was inexistent in 2004.

\subsection{Analysis and discussion}

\subsubsection{Evolution}

Brazil has been widely cited as a model in the quest to combat child labor due to the expressive reduction observed during the last decade (see Figure 1). Child labor increased by about 0.4 p.p. in 2005 but plummeted until 2013. Experts defend that such a reduction is mainly due to the rise of a bigger welfare state marked by the launch of the PBF program together with other social programs. Roughly speaking, from 2004 to 2013, the Brazilian government successfully cut the rate of child labor in half.

Notwithstanding the favorable scenario witnessed during the last decade, the passage from 2013 to 2014 was marked by an abrupt increase of about 0.9 p.p. in the rate of child labor. Although studies are yet to point to the potential causes of this increase, some believe it was simply a temporal fluctuation while others believe it to be an aftermath of economic crisis. The latter opinion seems more convincing since, according to Pochmann (2009), unemployment has been on the rise and inflation has caused most families to lose purchasing power, which might have led to the use of child labor to bolster family income.

Brazilian child labor experts point to a new challenge, which is that of the diminishing reduction of the child labor rate. This novel scenario can be observed in Figure 2, which decomposes the rate of child labor in rural and urban areas. The first observation from this figure is the preeminence of the rate of child labor in rural areas compared to urban areas. Specifically, the rate of child labor in rural areas was about four times the rate in urban areas in 2004 and about three and half times in 2014. Such preeminence may be partly explained by the level of poverty, the dominance of agricultural activities and difficulty of inspection in the rural areas.

(4) Apprentices were excluded by not considering adolescents aged 14 or 15 who work with a legal permit. This was possible because the PNAD survey provides a question which identifies labor activities with a work permit. 
Temidayo James Aransiola, Marcelo Justus

Figure 1

Percentage of child labor, 2004 - 2009 and $2011-2014$, Brazil

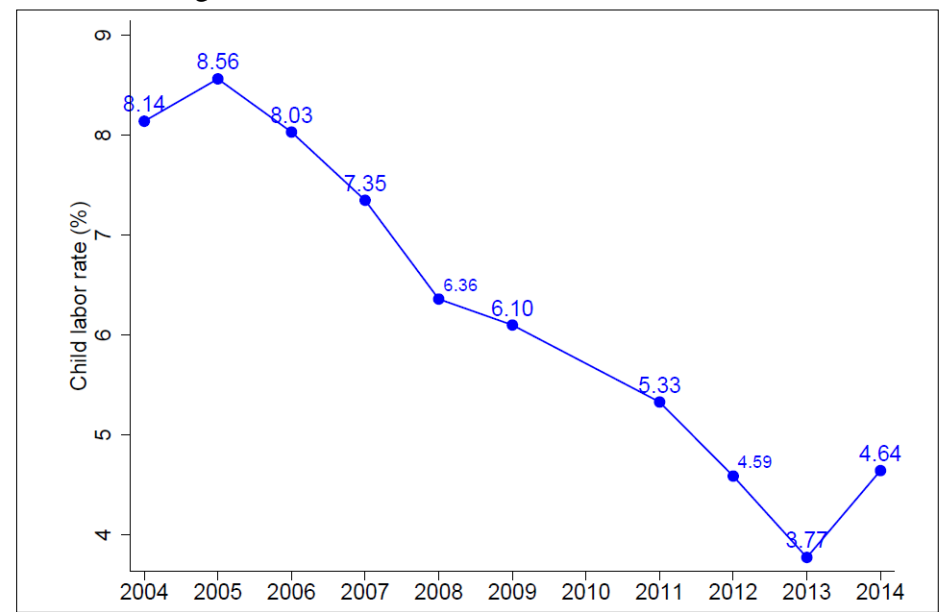

Source: Prepared using PNAD data.

Note: The confidence intervals for these rates are in the Appendix.

Figure 2

Percentage of child labor classified by rural and urban areas, 2004 - 2009 and 2011 - 2014, Brazil

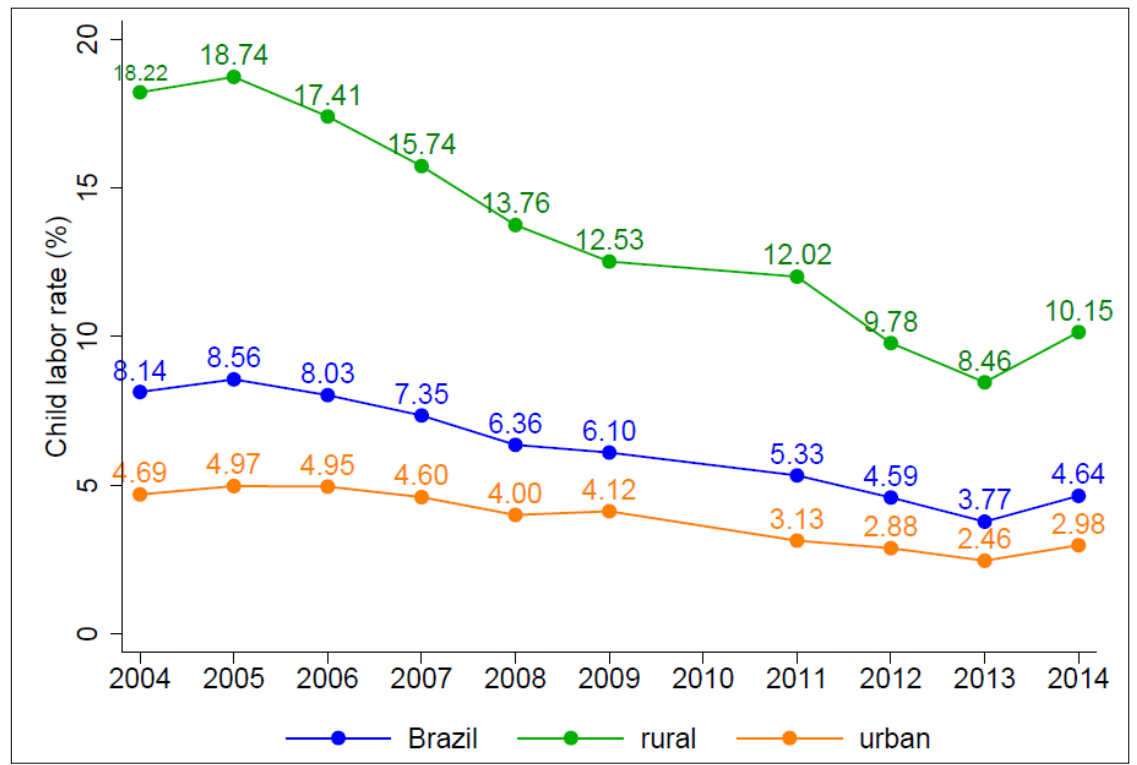

Source: Prepared using PNAD data.

Note: The confidence intervals for these rates are in the Appendix.

Aside from the comparative proportions of both areas, a more curious observation is the evolution of these proportions. Ignoring the recent shock, one observes that the rate of child labor in the rural area fell more sharply compared to that of urban areas. This perception induces 
to conclude that the expressive reduction of the child labor rate in Brazil is mainly driven by the reduction observed in the rural areas. This is upheld by the acute increase observed in 2014 for rural areas and Brazil as a whole, but not for urban areas.

Figure 3 and 4 illustrate the spatial distribution of child labor in Brazil in 2004 and 2014, respectively. As presented earlier, the percentage of child labor fell significantly in Brazil as a whole during the referred period. However, the concentration of higher rates is obvious in the North and Northeast compared to other regions. This is partly justifiable by the socioeconomic characteristics of these regions in terms of poverty, urbanization rate and preeminence of family agriculture. Comparing the map of the year 2004 to that of 2014, one perceives the homogenization of child labor rates in 2014. However, the in-depth comparison indicates that such homogenization is due to a higher reduction of child labor in the Northern and Northeast, and lower reduction in the Southern and Southeast regions.

Figure 3

Percentage of child labor, by state, Brazil, 2004

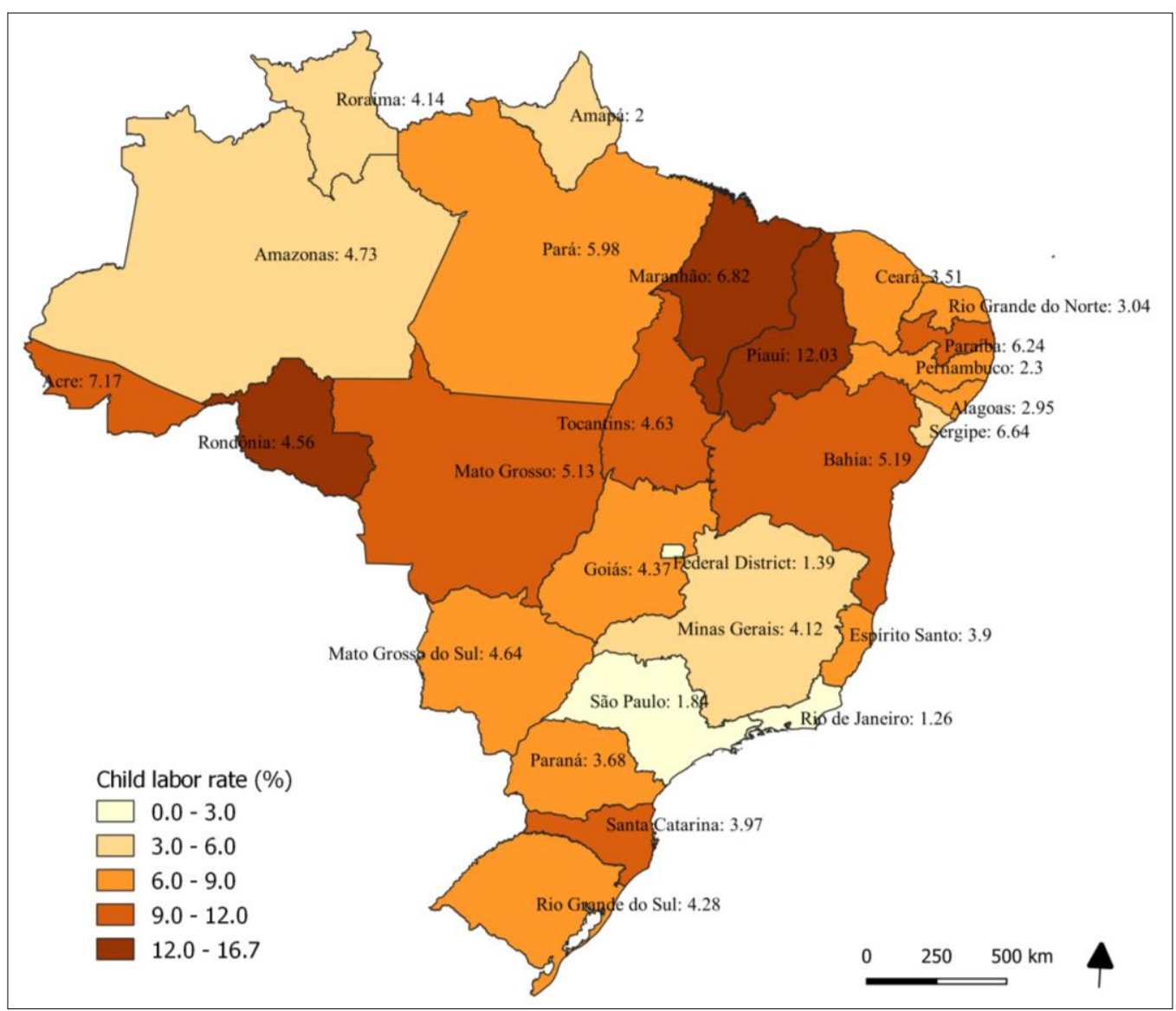

Source: Prepared using PNAD data.

Note: The confidence intervals for these rates are in the Appendix. 
The states with the highest rates of child labor in 2004, in reducing ranking order, were: Piauí, Rondônia, Maranhão, and Acre. In the same year, the lowest rates were observed in the Federal District, Rio de Janeiro, São Paulo, and Amapá (in increasing ranking order). Analogously for the year 2014, the states of Piauí, Acre, Maranhão, and Sergipe had the highest rates, while the states of Rio de Janeiro, São Paulo, Amapá, and the Federal District had the lowest rates. Impressively, the states of Pernambuco, Alagoas, Rondônia, Santa Catarina, and Ceará were able to significantly reduce the rate of child labor from 2004 to 2014.

Figure 4

Percentage of child labor by state, Brazil, 2014

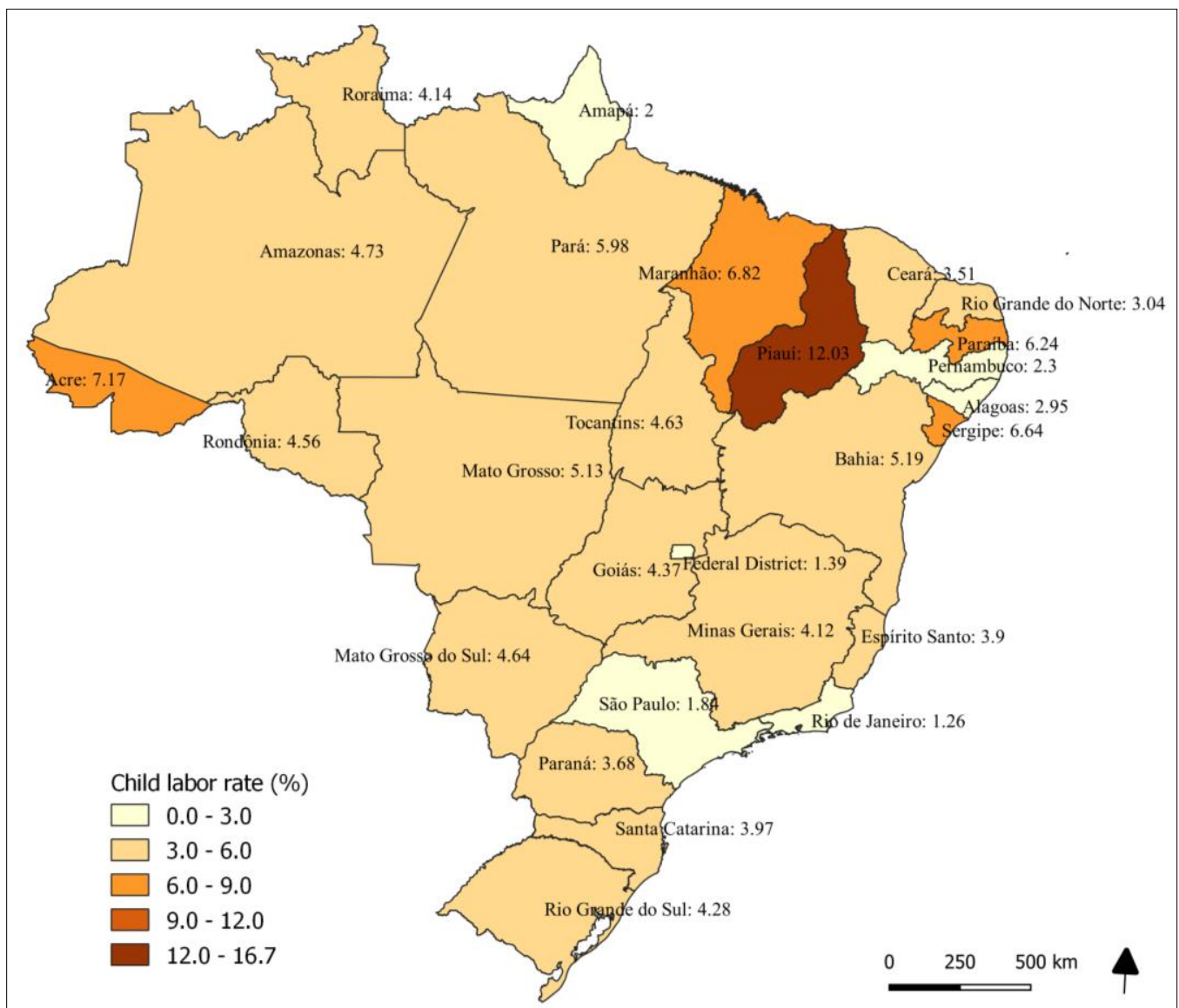

Source: Prepared using PNAD data.

Note: The confidence intervals for these rates are in the Appendix.

There is consensus in the literature that the agricultural sector is the primary employer of child laborers. According to PNAD data, in 2004, about 54\% of child laborers were working in the agricultural sector, while in 2014 this proportion was $46 \%$. Given that the majority of the 
children and adolescents in this sector are concentrated in family agriculture, about $88 \%$ of them were not paid and produced for own consumption in both years.

The trade and repair sector, which is second to agriculture, was responsible for the employment of $18 \%$ of child laborers in 2004 and $20 \%$ in 2014. Similarly, the service sector employed $18 \%$ and $21 \%$ of child laborers in 2004 and 2014, respectively. Although no less important, the industrial and construction sectors employed the least in both years.

Figure 5

Sectoral distribution of child labor, 2004, Brazil

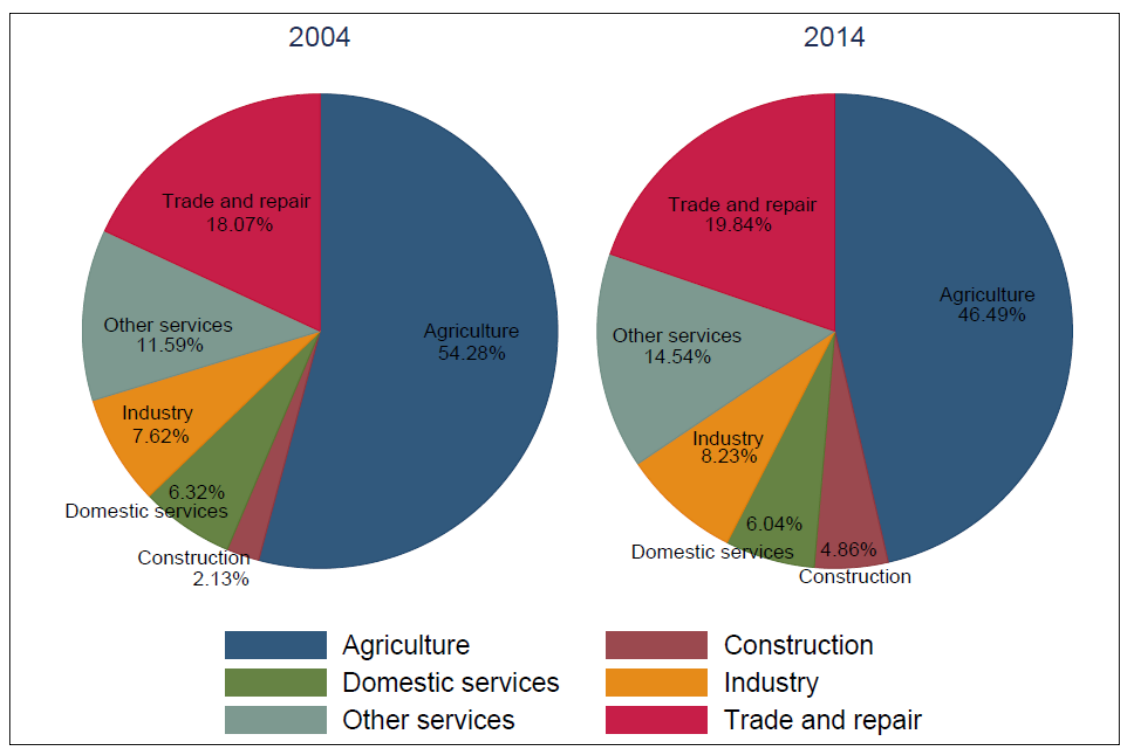

Source: Prepared using PNAD data.

\subsubsection{Labor Inspection}

Figure 6 and $7^{5}$ present the geographical distribution of the number of Labor Inspections conducted with a focus on child labor and the number of children that were effectively withdrawn from work in 2007 and 2014. There are two subfigures in each figure one for Labor Inspection coverage and the other for its effectiveness in reducing child labor. In line with ILO/SIT (2010), we recognize that the effectiveness of the Labor Inspection should not be exclusively measured by the number of children withdrawn from work, but also by the awareness-raising activities which precede inspection. However, the effect of such activities is counterfactual albeit acknowledged.

Inasmuch as the Labor Inspection activities were conducted in all states, regional concentration is observed. In the map (a) from Figure 6 we note that the allocation of inspection activities does not correspond to the rate of child labor in states (correlation of -0.07 and -0.08 in 2007 and 2014, respectively). In 2007, the states of Piauí and Maranhão had the highest rates

(5) In order to avoid polluing the figures, the maps are not labeled. For identification of the states refer to Figure 3 or 4. 
of child labor but were ranked in the 20th and 18th positions concerning the number of conducted inspections. Moreover, the states of Ceará, Mato Grosso do Sul and Minas Gerais are first, second and third, respectively, as to the number of conducted inspections, but are 5th 17th and 18th, respectively, as to the highest rates of child labor. In fact, we observe that the highest rates of child labor are concentrated in the Northeast region and the lowest are observed in the Midwest and Southeast regions. However, the Northeast region is less prioritized than the Midwest and Southeast regions concerning inspection allocation. In this case, the distribution of Labor Inspections among states is paradoxical since the major objective of the inspection activities is to reduce child labor.

To understand this paradoxical distribution one has to consider the design and features of the inspections and how they relate to other constitutional apparatus. Firstly, it is important to recall that the Labor Inspection depends on reported complaints in the region. However, this does not justify the paradoxical distribution since the complaints are only part of what guides the planning process. Still, regarding design, it is worth noting that inspectors visit businesses and workplaces, but overlook child labor outside organized establishments. Take for example children who work as street vendors, in family agriculture, in informal urban activities or as domestic workers or housekeepers. These types of child labor are hardly reached due to their invisibility and difficulty to pinpoint. Another dilemma is faced concerning the design of the Labor Inspection - the focus on child labor in regions where the incidence is higher but invisible or on child labor in regions where the incidence is relatively low but visible. These alternatives are not mutually exclusive but they may concentrate Labor Inspection in more urbanized regions (as observed in Figure 6) since child labor in some activities is not visible to inspections.

The incompatibility of inspection activities and the Brazilian constitutional apparatus of inviolability of homes without judicial authorization (Art. 5 §XI of the 1988 Federal Constitution) inhibits effective access of inspectors to households. This impedes the withdrawal of children and adolescents from family agriculture or domestic activities. Specifically, 38\% and $42 \%$ of child laborers were engaged in family agriculture in 2004 and 2014, respectively, and about $6 \%$ were domestic workers. Therefore, about $42 \%$ and $46 \%$ of child laborers were invisible to inspections in the years 2004 and 2014.

In terms of the effectiveness of Labor Inspection on child labor, it is notable in Figure $6 \mathrm{~b}$ that a greater number of children were withdrawn from work in the Northeast region compared to the Midwest and Southeast regions. For instance, the state of Maranhão, which had the highest rate of child labor in 2007 and was ranked in the 18th position on the inspection's priority list, had the second-highest number of children withdrawn from work. Conversely, the states of Mato Grosso do Sul and Minas Gerais, which had lower child labor rates but were highly prioritized for inspection were not at the top of the list of states that withdrew children from work as a result of inspections. 
Figure 6

Rate of child labor, number of Labor Inspections and number of children withdrawn from work, by state, Brazil, 2007

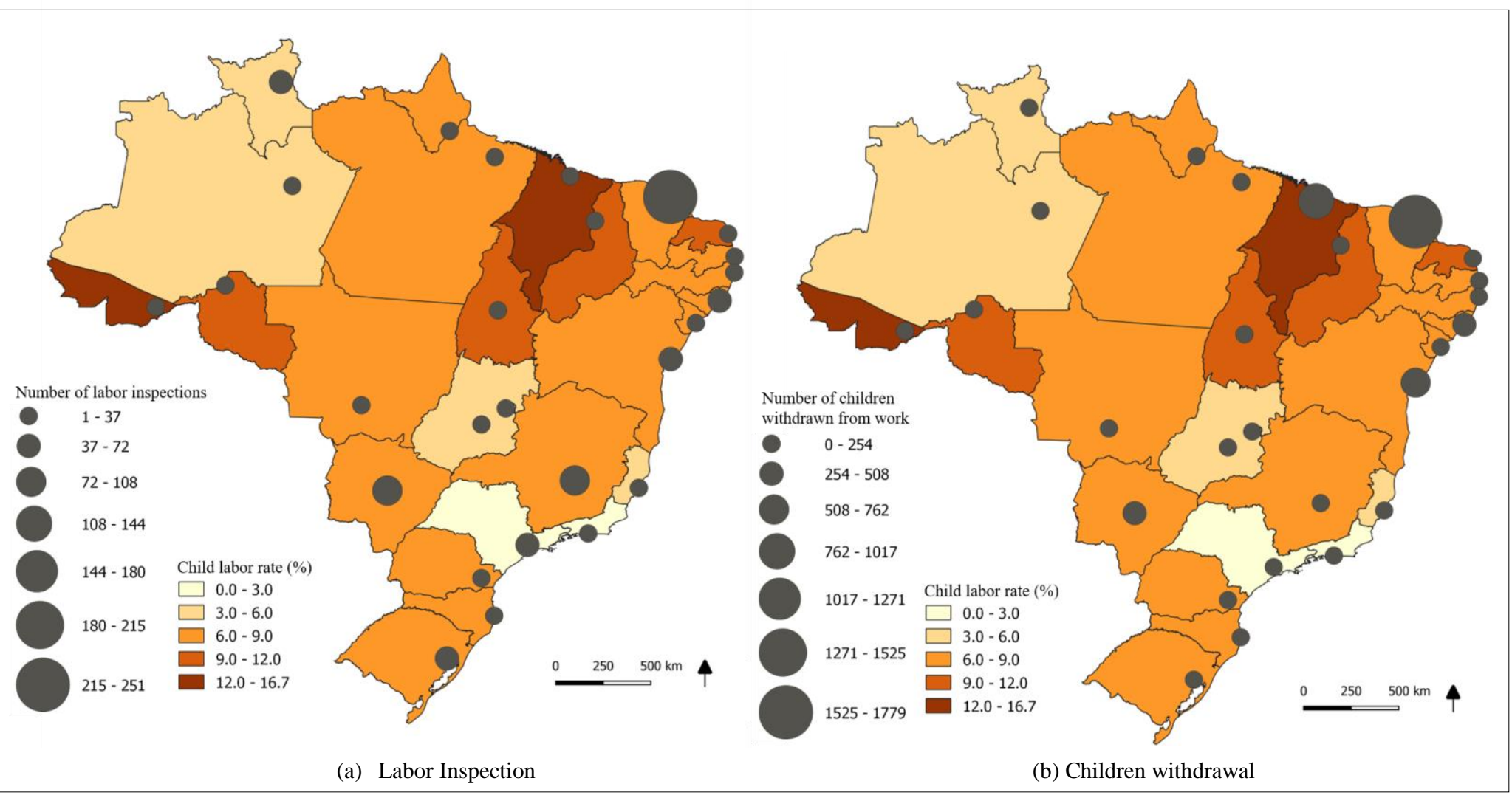

Source: Prepared using PNAD and Information System of Child Labor (SITI) data.

Note: The Labor Inspection data are in the Appendix. 
Figure 7

Rate of child labor, number of Labor Inspections and number of children withdrawn from work, by state, Brazil, 2014

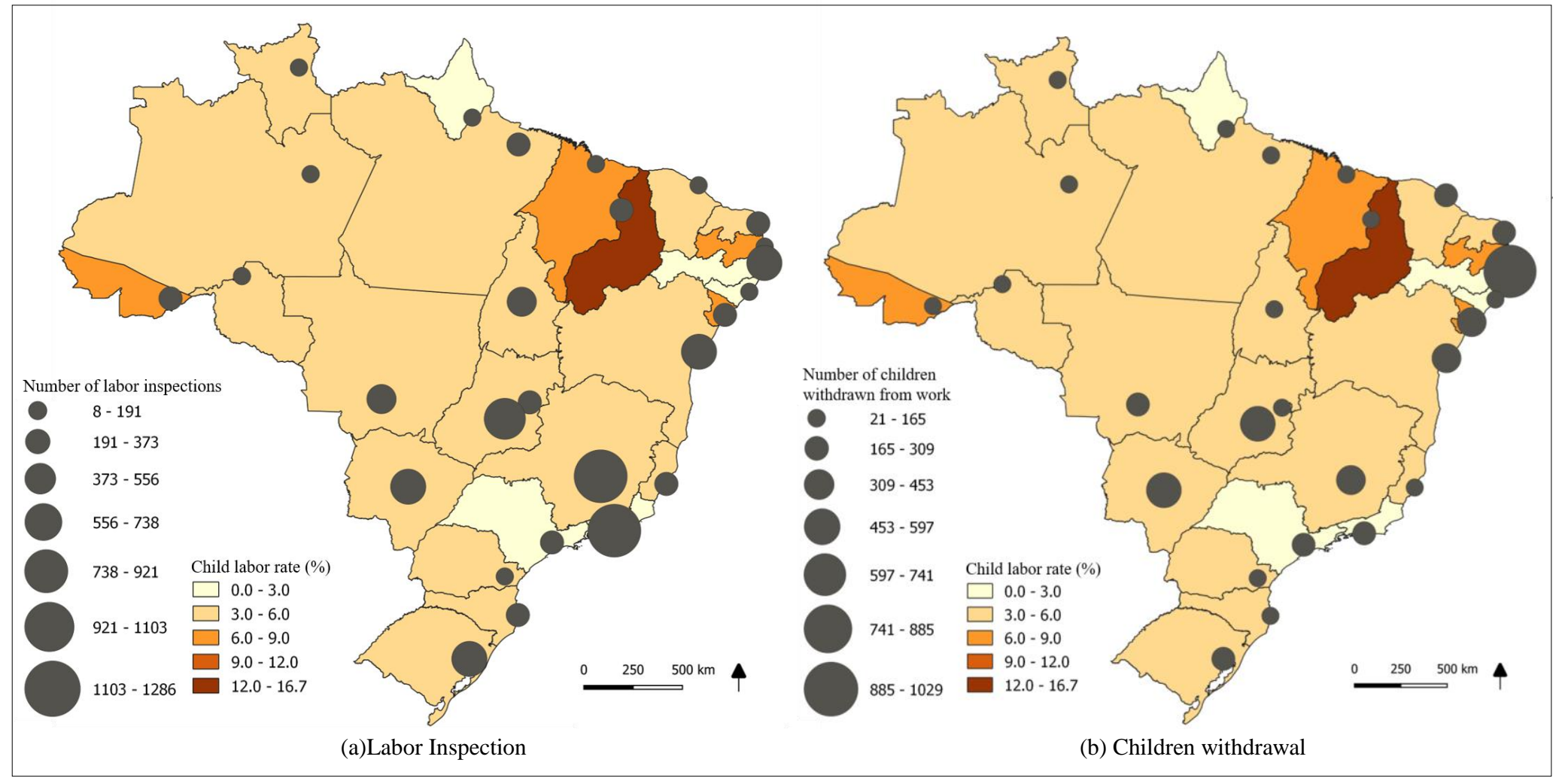

Source: Prepared using PNAD and Information System of Child Labor (SITI) data.

Note: The Labor Inspection data are in the Appendix. 
The first observation from Figure 7 is the general increase in the number of inspection activities in 2014. It is clear that the number of Labor Inspections increased more in the Midwest, Southeast and Southern regions compared to the others. Still, in 2014, none of the states with the highest rate of child labor, with the exception of Pernambuco, were prioritized on the inspection allocation list. In other words, the negative correlation between the rate of child labor and the number of conducted inspections, which was observed in 2007, persisted in 2014. However, we noted that despite the concentration of Labor Inspections in the Southern and Southeast regions, the Labor Inspection withdrew more children and adolescents from work in the Northeast region.

The effectiveness of inspections to reduce child labor was empirically confirmed by Almeida (2015). This author concluded that for the years 2000 and 2010, each percentage increase in the number of inspections reduces the proportion of child laborers between the ages of 10 and 17 by $0.22 \%$ and $0.26 \%$, respectively. In absolute terms, inspection accounted for the reduction of, approximately, 8,658 and 8,856 child laborers in the years 2000 and 2010, respectively. Despite the applauded effect, the authors acknowledged that the number of inspections and inspectors are still relatively small. However, this highly depends on the number of reported cases and, thus, the attitude of society towards child labor.

\subsubsection{Conditional cash transfer}

Figure 8 illustrates the geographic distribution of the PBF benefits among states by their respective child labor rates in 2004 and 2014. The first observation from Figure $8 \mathrm{a}$ and $8 \mathrm{~b}$ is that of a similar allocation pattern of the PBF benefits in 2004 and 2014. We also observe concentration in the Northeast and Southeast regions in both years.

Comparing with child labor, there is no clear correlation between rates and the number of beneficiary families attended by the PBF in 2004 and 2014 (correlation of 0.136 and \$\$-0.047 in 2007 and 2014, respectively). In fact, we observe contradictory distribution for some states in both years. For example, the state of Acre has one of the highest rates of child labor but is modestly attended by the program, compared to São Paulo which has the lowest rate of child labor but is one the most privileged by the PBF program. A similar relationship was found between the states of Sergipe and the Federal District. It is perceptible from these maps that the main objective of the program is quite distant from directly reducing child labor. However, one can not be too demanding since the program only combats child labor through one of its conditionalities. It is also relevant to recall that participation in the PBF is voluntary and limited to the poor population.

To verify the potential reach of the PBF to address child labor, we analyze the poverty eligibility condition. Figure 9 and 10 present the classification of child laborers by their monthly family income per capita for the years 2004 and 2014. Note that the average family income 
presented does not include children's income. Thus, only adults' income and legal income of adolescents in apprenticeships were considered. It is also important to emphasize that the analysis of these proportions exclusively concerns child laborers and is not comparative to nonchild laborers. Moreover, the class intervals were strategically chosen to account for the extreme poverty lines ( $\mathrm{R} \$ 69$ and $\mathrm{R} \$ 77$ per capita for the years 2004 and 2014, respectively), poverty lines ( $R \$ 137$ and $R \$ 154$ per capita for the years 2004 and 2014, respectively) and minimum wage levels ( $\mathrm{R} \$ 260$ and $\mathrm{R} \$ 745$ for 2004 and 2014, respectively). These poverty and extreme poverty lines were used to stipulate the eligibility of families in the PBF conditional cash transfer program in both years. Given that the objective here is to verify the relationship between family income strata and the incidence of child labor, the few cases of negative net family income were ignored ${ }^{6}$.

For the year 2004, we observe that about $35 \%$ of child laborers were from extremely poor families, while about $27 \%$ were from poor families. In other words, about $62 \%$ of child laborers were from families below the poverty line. Moreover, it is observable that the proportion of child laborers from families with average family income per capita between the poverty line and the minimum wage is lower compared to the anterior class interval. Taking into account the relative amplitude of each class interval, one can deduce that the proportion of child laborers falls as the family income per capita increases. Therefore, our overall conclusion is that the distribution of child labor by family income levels is skewed right, thus, a positive relationship between family poverty and child labor is evident. This observation reinforces the publication of ILO (2016) on how an increase in real wage may promote decent work, especially in developing countries.

(6) The only cases of negative net family income were for families with no working adults or for cases in which children's income exceeded the total adult income from the same family, however, such cases were very few. 
Figure 8

Rate of child labor and the number of families covered by the PBF program, by state, Brazil, 2004 and 2014.

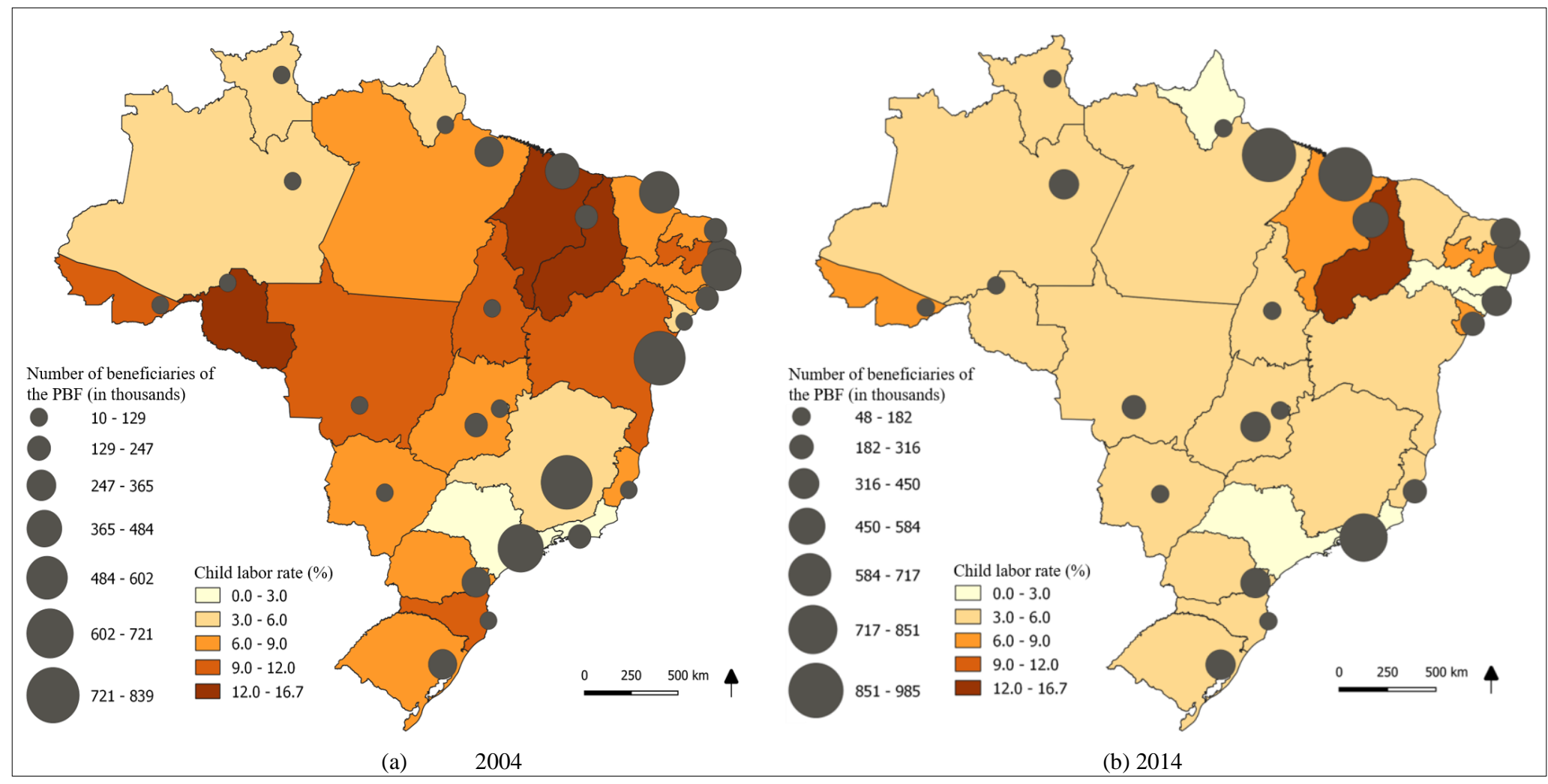

Source: Prepared using PNAD and the Ministry of Social Development (MDE) data Note: The Bolsa Família data are in the Appendix. 
Figure 9

Percentage of child labor by average family income, Brazil, 2004

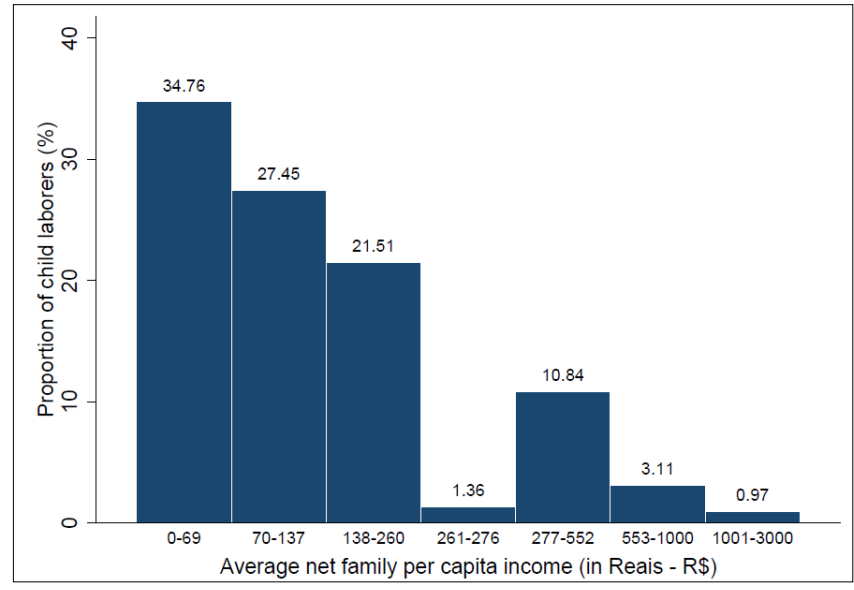

Source: Prepared using PNAD data.

Note: Income of children and adolescents were deducted from total family income.

An overview of the same exercise for the year 2014 prompts curiosity, especially concerning the distribution which seems normal and not skewed right as observed for the year 2004. Specifically, in the year 2014, only about $6 \%$ of child laborers were from extremely poor families, while about $13 \%$ were from poor families. Cumulatively, only about $19 \%$ were from families below the poverty line. However, it is reasonable to imagine that this poverty line is very low, so we double the poverty line (value of $\mathrm{R} \$ 308$ ). Still, more than half of the child laborers (about 55\%) were from families above these income strata in 2014. Amplifying the poverty line further, we assumed that each member of the family (including adults and children) earns the minimum wage (value of $\mathrm{R} \$ 742$ ). Yet, almost $20 \%$ of child laborers work.

Figure 10

Percentage of child labor by average family income, Brazil, 2014

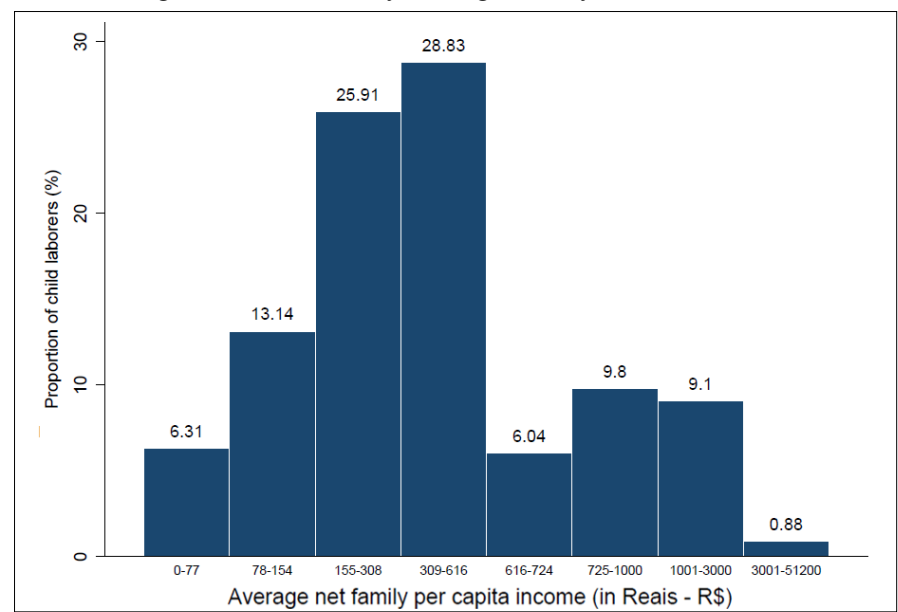

Source: Prepared using PNAD data.

Note: Income of children and adolescents were deducted from total family income. 
Such a change in the profile of child laborers from 2004 to 2014 may have severe implications on the effectiveness of government social programs to reduce child labor. In our case, the coverage of the PBF program concerning child labor was highly limited in 2014 since only poor and extremely poor families could participate. Specifically, about $31 \%$ and $81 \%$ of child laborers were not eligible to participate in this cash transfer program in 2004 and 2014, respectively. Nevertheless, we must recognize that the reduction of child labor is not the primary objective of the program. Moreover, such a change in the poverty profile of child laborers should not be treated as misfortune since it may be as a result of the general reduction of poverty and income inequality, which was partly reinforced by cash transfer programs, as pointed out by Hoffmann (2006), Soares et al. (2006) and Medeiros et al. (2007).

Although not the focus here, it is worth remembering that the PETI program attends families above the poverty line. However, we believe that the value transferred to families in this program is too low to attract participation since such families are not considered poor and children are offered higher values in the informal labor market, while albeit being subjected to unfair working conditions.

At this point, it is not surprising that empirical studies barely recognize the effectiveness of the PBF in reducing child labor, particularly in recent years (see Araujo et al., 2010; Cacciamali et al., 2010; Aquino et al., 2010; Nascimento, 2013). Findings from these authors converge concerning the role of the PBF to increase school attendance, but not to reduce child labor. In short, these authors found a higher probability of child labor among beneficiaries of the PBF program. Do Nascimento et al. (2016) contributed by concluding that participation in the program has no significant effect on the probability of a child to work or on working hours. However, evidence was found that the sum transferred to families contributed to reducing the probability of child labor, likewise working hours. This indicates that child labor can be reduced if benefits are generous.

This paradoxical result is similar to that found for the previous CCTs in Brazil, especially the Bolsa Escola Program. In particular, Cardoso and Souza (2004) and Ferro and Kassouf (2005) concluded that, despite reducing working hours, child laborers from beneficiary families are most likely to conciliate work and study and are not convinced to leave work. Nonetheless, in posterior studies, Ferro et al. (2010) found that the Bolsa Escola Program contributed to reducing the probability of children from beneficiary families to work and increasing the school enrollment of the same children.

In sum, we do not find any clear consensus in the literature concerning the effect of CCTs in Brazil. However, we are quite convinced based on our descriptive analysis that the spatial allocation and domain of the PBF is contradictory and limited regarding the scale of child labor in Brazilian states. 


\section{Concluding remarks}

The rate of child labor indeed reduced expressively during the period between 2004 and 2014, largely due to the reduction in rural areas. Still, we noted that the decrease in child labor was greater in states from the North and Northeast regions, leading to slight homogenization of rates in Brazil as a whole in 2014. Child labor is concentrated in the agricultural sector, especially in family agriculture where children and adolescents are unpaid and produce for own consumption.

As for governmental countermeasures, firstly, we found that labor inspection with a focus on child labor has a contradictory allocation among states in the sense that states with higher rates are not prioritized for inspections. Our readings clarified that such a contradiction exists as a result of limits encountered during the planning and execution process of inspections. One one hand, the annual plans which guide the allocation of inspections depend on reported cases of child labor in regions. Thus, the allocation is conditioned to the culture and attitude of the population towards the use of child labor. On the other hand, inspectors also face limitations due to inaccessible sectors such as domestic activities, family agriculture, and informal urban services. These areas are invisible to inspectors, particularly because of the difficulty to pinpoint child laborers engaged in urban services and the right of inviolability of homes stipulated by the Brazilian Federal Constitution. Such limits tend to divert inspections from invisible and the worst forms of child labor, thus, regionalizing inspection activities.

Similarly, we observed a contradictory allocation of benefits of the PBF program. However, in this case, we acknowledge that the main objective of the program is to reduce poverty and not child labor.

Studies have pointed to the reduction of poverty and income inequality in Brazil, partly as a result of governmental cash transfer programs designed to attend the poor population. This trend coincided with the expressive reduction of the child labor rate in Brazil, however, in an asymmetric manner since only the poor population are attended by programs such as the PBF. Particularly, we found that the poverty conditionality for participation in this program makes a portion of child laborers ineligible for not being from families below the poverty line. The portion was about $31 \%$ in 2004 and about $81 \%$ in 2014 .

We emphasize that such a change in child laborers' profiles should not be addressed as a misfortune. In fact, the PBF might have played a satisfactory role regrading families below the poverty line. Therefore, we believe that it is time for the PETI to assume a major role in combating child labor taking place beyond the poverty line. For this, adjustments have to be made to the program such as raising the values of benefits in order to motivate families to voluntarily participate. Moreover, such an adjustment must consider the level of family income of these child laborers and, more specifically, the wage which the informal labor market offers.

Concisely, we believe that policies designed to reduce child labor should be adjusted to fit the evolution of the child labor rate and profile in Brazilian states to overcome the limits and contradictions highlighted in this study. 
This study provides relevant contributions to the literature on child labor in Brazil but faces some limitations, particularly that it is merely descriptive. No empirical model was estimated to test the association of the governmental countermeasures with child labor rates but we assume that they should be associated based on their design and objectives. Therefore, any perceived connotation of association is simply speculative. We also acknowledge that the cross-sectional analysis of two periods does not account for the temporal and structural variations that occurred between the years 2004 and 2014. Lastly, there are many other factors apart from the Labor Inspection and the Bolsa Família program that play a significant role on child labor rates and are not addressed in this study. Nonetheless, significant questions were raised to guide future empirical studies and policy thinking. In particular, we suggest an empirical assessment of the effect of Labor Inspection on the child labor rate if more data is provided in the $f$ uture.

\section{References}

ALMEIDA, R. B. O efeito das fiscalizações do trabalho para a redução do trabalho infantil no Brasil. Ph. D. thesis - Escola Superior de Agricultura Luiz de Queiroz (USP/ESALQ), 2015.

AQUINO, J. M.; FERNANDES M. M.; PAZELlO, E. T.; SCORZAFAVE, L. G. et al. Trabalho infantil: persistência intergeracional e decomposição da incidência entre 1992 e 2004 no Brasil rural e urbano. Revista de Economia Contemporânea, v. 14, n. 1, p. 61-84, 2010.

ARANSIOLA, T. J.; JUSTUS, M. Child labor hazard on mental health: evidence from Brazil The Journal of Mental Health Policy and Economics, v. 21, n. 2, p. 49-58, 2018.

ARAUJO, G. S.; RIBEIRO, R.; NEDER, H. D. Impactos do programa Bolsa Família sobre o trabalho de crianças e adolescentes residentes na área urbana em 2006. EconomiA, v. 11, n. 4, p. 57-102, 2010.

BALAND, J. M.; ROBINSON, J. A. Is child labor inefficient? Journal of Political Economy, v. 108, n. 4, p. 663-679, 2000.

BASU, K. Child labor: cause, consequence, and cure, with remarks on international labor standards. Journal of Economic Literature, v. 37, n. 3, p. 1083-1119, 1999.

CACCIAMALI, M. C.; TATEI, F.; BATISTA, N. F. Impactos do Programa Bolsa Família federal sobre o trabalho infantil e a frequência escolar. Revista de Economia Contemporânea, v. 14, n. 2, p. 269-301, 2010.

CARDOSO, E.; SOUZA, A. P. The impact of cash transfers on child labor and school attendance in Brazil. Vanderbilt University Department of Economics, 2004. (Working Paper, n. 407).

COMISSÃO NACIONAL DE. ERRADICAÇÃO DO TRABALHO INFANTIL - CONAETI. Plano Nacional de Prevenção e Erradicação do Trabalho Infantil e Proteção Adolescente Trabalhador. Brasília: Ministério do Trabalho e Emprego, 2011. 
DO NASCIMENTO, A. R.; KASSOUF, A. L. et al. Trabalho infantil: impacto do Programa Bolsa Família. In: PROCEEDINGS of the Brazilian Economics Meeting, n. 232, 2016.

EMERSON, P. M.; SOUZA, A. P. Is there a child labor trap? intergenerational persistence of child labor in Brazil. Economic Development and Cultural Change, v. 51, n. 2, p. 375-398, 2003.

EMERSON, P. M.; SOUZA, A. P. Is child labor harmful? the impact of working earlier in life on adult earnings. Economic Development and Cultural Change, v. 59, n. 2 p. 345-385, Jan. 2011.

FEITOSA, I. C. N.; GOMES M. A. F.; GOMES, M. V. S.; DIMENSTEIN, M. O trabalho precoce e as políticas de saúde do trabalhador em Natal. Estudos de Psicologia, v. 6, n. 2, p. 259-268, 2001.

FERRO, A. R.; KASSOUF, A. L. Avaliação do impacto dos programas Bolsa-Escola sobre o trabalho infantil no Brasil. Pesquisa e Planejamento Econômico, v. 35, n. 3, p. 417-444, 2005.

FERRO, A. R.; KASSOUF, A. L.; LEVISON, D. The impact of conditional cash transfer programs on household work decisions in Brazil. Research in Labor Economics, v. 31, p. 193$218,2010$.

GUARCELLO, L.; LYON, S.; ROSATI, F. C.; VALDIVIA. Children's non-market activities and child labour measurement: a discussion based on household survey data. Understanding Children's Work (UCW Programme), 2007. (Technical Report).

HOFFMANN, R. Transferências de renda e a redução da desigualdade no brasil e cinco regiões entre 1997 e 2004. Econômica, v. 8, n. 1, p. 55-81, 2006.

ILO/SIT. The good practices of labor inspection: the prevention and eradication of child labor. SIT/MTE/ILO, 2010.

ILO. World Employment and Social Outlook 2016: transforming jobs to end poverty. International Labour Organization, 2016.

JUSTUS, M.; KAWAMURA, H.; KASSOUF, A. L. What is the best age to enter the labor market in Brazil today? EconomiA, v. 16, n. 2, p. 235-249, 2015.

KASSOUF, A. L. Trabalho infantil: escolaridade x emprego. EconomiA, v. 2, n. 2, p. 549$586,2001$.

KASSOUF, A. L.; JUSTUS, M. Trabalho infantil no meio rural brasileiro: evidências sobre o "paradoxo da riqueza". Economia Aplicada, v. 14, n. 3, p. 339-353, 2010.

LOPEZ-CALVA, L. International labor standards: history, theories and policy. Chapter Social Norms, Coordination and Policy Issues in the Fight Against Child Labor. Blackwell, 2003. 
MEDEIROS, M.; BRITTO, T.; SOARES, F. Transferência de renda no brasil. Novos EstudosCebrap, n. 79, p. 5-21. 2007.

NASCIMENTO, A. R. Impacto do Programa Bolsa Família sobre as decisões de trabalho das crianças: uma análise utilizando os microdados da PNAD. Ph. D. thesis - Escola Superior de Agricultura Luiz de Queiroz, 2013.

NASCIMENTO, A. R. D.; KASSOUF, A. L. Trabalho infantil: impacto do Programa Bolsa Famlia. Proceedings of the 42nd Brazilian Economics Meeting, n. 232, ANPEC. Brazilian Association of Graduate Programs in Economics, 2016.

POCHMANN, Marcio. O trabalho na crise econômica no Brasil: primeiros sinais Estudos Avançados, v. 23, n. 66, p. 41-52, 2009.

REPÓRTER BRASIL. Brasil livre de trabalho infantil: contribuições para o debate sobre a eliminação das piores formas do trabalho de crianças e adolescentes. Repórter Brasil Organização de Comunicação e Projetos Sociais, 2013.

ROSADO, S.; LUCIANA, S. Relatório final da comissão parlamentar de inquérito destinada a apurar a exploração do trabalho infantil no Brasil e dá outras providências. CPI -Trabalho Infantil, 2014. (Technical Report).

SOARES, F. V.; SOARES, S.; MEDEIROS, M.; OSÓRIO, R. G. Programas de transferência de renda no Brasil: impactos sobre a desigualdade. Brasília: Instituto de Pesquisa Econômica Aplicada (Ipea), 2006.

SOARES, S.; SÁTYRO, N. Bolsa Família 2003-2010: avanços e desafios, Chapter O Programa Bolsa Família: desenho institucional e possibilidades futuras. Brasília: Ipea, 2010, p. 25-57. 
Temidayo James Aransiola, Marcelo Justus

\section{Appendix}

Table 1

Child labor Rate, Brazil, rural and urban areas, 2004 a 2014 (\%)

\begin{tabular}{c|c|c|c|c|c|c|c|c|c}
\hline & \multicolumn{3}{|c|}{ Brazil } & \multicolumn{3}{c|}{ Rural } & \multicolumn{3}{c}{ Urban } \\
\hline Year & Rate & \multicolumn{2}{|c|}{$95 \%$ C.I. } & Rate & \multicolumn{2}{c|}{$95 \%$ C.I. } & Rate & \multicolumn{2}{c}{$95 \%$ C.I. } \\
\hline 2004 & 8.137 & 6.680 & 9.595 & 0.191 & 0.185 & 0.197 & 4.299 & 4.147 & 4.451 \\
\hline 2005 & 8.560 & 7.008 & 10.112 & 0.203 & 0.197 & 0.210 & 4.482 & 4.327 & 4.637 \\
\hline 2006 & 8.028 & 6.782 & 9.274 & 0.182 & 0.176 & 0.188 & 4.335 & 4.183 & 4.488 \\
\hline 2007 & 7.349 & 6.236 & 8.462 & 0.165 & 0.160 & 0.171 & 4.205 & 4.052 & 4.359 \\
\hline 2008 & 6.359 & 5.349 & 7.368 & 0.147 & 0.141 & 0.152 & 3.741 & 3.592 & 3.890 \\
\hline 2009 & 6.097 & 5.031 & 7.164 & 0.136 & 0.130 & 0.141 & 3.864 & 3.713 & 4.014 \\
\hline 2011 & 5.328 & 4.338 & 6.318 & 0.131 & 0.125 & 0.137 & 2.858 & 2.719 & 2.997 \\
\hline 2012 & 4.586 & 3.715 & 5.458 & 0.108 & 0.103 & 0.114 & 2.625 & 2.491 & 2.760 \\
\hline 2013 & 3.773 & 3.107 & 4.438 & 0.096 & 0.090 & 0.101 & 2.364 & 2.234 & 2.493 \\
\hline 2014 & 4.641 & 3.764 & 5.518 & 0.109 & 0.103 & 0.115 & 2.693 & 2.553 & 2.834 \\
\hline Soury
\end{tabular}

Source: Prepared using data from PNADs.

Table 2

Child labor Rate, by states, 2004, 2007, 2014 (\%)

\begin{tabular}{|c|c|c|c|c|c|c|c|c|c|}
\hline \multirow{3}{*}{$\begin{array}{l}\text { States } \\
\text { Rondônia (RO) } \\
\end{array}$} & \multicolumn{3}{|c|}{2004} & \multicolumn{3}{|c|}{2007} & \multicolumn{3}{|c|}{2014} \\
\hline & \multirow{2}{*}{$\begin{array}{l}\text { Rate } \\
12.9\end{array}$} & \multicolumn{2}{|c|}{$95 \%$ C.I. } & \multirow{2}{*}{$\begin{array}{l}\text { Rate } \\
9.56\end{array}$} & \multicolumn{2}{|c|}{ 95\% C.I. } & \multirow{2}{*}{$\begin{array}{l}\text { Rate } \\
4.56\end{array}$} & \multicolumn{2}{|c|}{$95 \%$ C.I. } \\
\hline & & 11.2 & 14.7 & & 8.04 & 11.1 & & 3.45 & 5.66 \\
\hline Acre (AC) & 11.3 & 9.52 & 13.1 & 13.4 & 11.5 & 15.3 & 7.17 & 5.66 & 8.67 \\
\hline Amazonas (AM) & 5.79 & 4.89 & 6.69 & 5.36 & 4.53 & 6.2 & 4.73 & 3.94 & 5.53 \\
\hline Roraíma (RR) & 4.59 & 2.83 & 6.35 & 5.17 & 3.3 & 7.04 & 4.14 & 2.44 & 5.84 \\
\hline Pará (PA) & 8.7 & 7.94 & 9.47 & 7.15 & 6.44 & 7.86 & 5.98 & 5.29 & 6.66 \\
\hline Amapá (AP) & 4.2 & 2.91 & 5.5 & 6.02 & 4.44 & 7.59 & 2 & 0.92 & 3.08 \\
\hline Tocantins (TO) & 9.86 & 8.3 & 11.4 & 10.2 & 8.57 & 11.8 & 4.63 & 3.43 & 5.83 \\
\hline Maranhão (MA) & 12.3 & 10.8 & 13.8 & 13.3 & 11.7 & 14.9 & 6.82 & 5.71 & 7.92 \\
\hline Piauí (PI) & 16.7 & 14.6 & 18.7 & 11.2 & 9.45 & 13 & 12 & 10 & 14 \\
\hline Ceará (CE) & 8.14 & 7.42 & 8.86 & 7.66 & 6.96 & 8.36 & 3.51 & 2.87 & 4.15 \\
\hline Rio Grando do Norte (RN) & 6.65 & 5.31 & 7.99 & 9.23 & 7.71 & 10.8 & 3.04 & 1.89 & 4.2 \\
\hline Paraíba (PB) & 10.9 & 9.51 & 12.4 & 8.06 & 6.75 & 9.36 & 6.24 & 4.84 & 7.65 \\
\hline Pernambuco (PE) & 7.06 & 6.39 & 7.73 & 6.64 & 5.97 & 7.31 & 2.3 & 1.81 & 2.79 \\
\hline Alagoas (AL) & 8.65 & 7.28 & 10 & 8.23 & 6.77 & 9.69 & 2.95 & 1.96 & 3.95 \\
\hline Sergipe (SE) & 5.3 & 4.07 & 6.54 & 6.13 & 4.85 & 7.4 & 6.64 & 5.21 & 8.06 \\
\hline Bahia (BA) & 9.82 & 9.16 & 10.5 & 8.37 & 7.75 & 8.98 & 5.19 & 4.56 & 5.82 \\
\hline Minas Gerais (MG) & 5.73 & 5.21 & 6.26 & 6.2 & 5.63 & 6.76 & 4.12 & 3.59 & 4.66 \\
\hline Espírito Santo (ES) & 7.46 & 6.1 & 8.81 & 5.52 & 4.32 & 6.71 & 3.9 & 2.76 & 5.05 \\
\hline Rio de Janeiro (RJ) & 1.83 & 1.44 & 2.21 & 1.96 & 1.56 & 2.36 & 1.26 & 0.9 & 1.62 \\
\hline São Paulo (SP) & 2.97 & 2.61 & 3.33 & 2.77 & 2.41 & 3.13 & 1.84 & 1.5 & 2.17 \\
\hline Paraná (PR) & 8.43 & 7.57 & 9.29 & 7.87 & 7.02 & 8.71 & 3.68 & 3.01 & 4.35 \\
\hline Santa Catarina (SC) & 9.39 & 8.11 & 10.7 & 8.17 & 6.9 & 9.43 & 3.97 & 2.96 & 4.98 \\
\hline Rio Grande o Sul (RS) & 7.32 & 6.65 & 7.99 & 6.09 & 5.43 & 6.75 & 4.28 & 3.63 & 4.92 \\
\hline Mato Grosso do Sul (MS) & 6.32 & 5.12 & 7.51 & 6.92 & 5.64 & 8.2 & 4.64 & 3.39 & 5.88 \\
\hline Mato Grosso (MT) & 9.63 & 8.29 & 11 & 7.37 & 6.13 & 8.62 & 5.13 & 3.96 & 6.3 \\
\hline Goiás (GO) & 6.39 & 5.56 & 7.23 & 5.37 & 4.59 & 6.15 & 4.37 & 3.56 & 5.17 \\
\hline Destrito Federal (DF) & 0.62 & 0.3 & 0.94 & 1.57 & 1.04 & 2.1 & 1.39 & 0.81 & 1.97 \\
\hline
\end{tabular}

Source: Prepared using data from PNADs.

Note: C.I. is the Confidence Interval at $95 \%$. 
Table 3

Labor Inspection and Bolsa Família program in Brazilian states

\begin{tabular}{|c|c|c|c|c|c|c|}
\hline States & LI2007 & Children2007 & LI2014 & Children2014 & PBF2004 & PBF2014 \\
\hline Rondônia (RO) & 1 & 34 & 73 & 34 & 54,942 & 114,170 \\
\hline Acre (AC) & 2 & 59 & 239 & 56 & 28,851 & 78,561 \\
\hline Amazonas (AM) & 4 & 36 & 150 & 102 & 104,135 & 358,516 \\
\hline Roraíma (RR) & 46 & 0 & 105 & 67 & 14,522 & 48,104 \\
\hline Pará (PA) & 23 & 112 & 290 & 105 & 259,641 & 887,426 \\
\hline Amapá (AP) & 4 & 58 & 65 & 133 & 10,256 & 55,527 \\
\hline Tocantins (TO) & 13 & 152 & 431 & 21 & 55,305 & 139,295 \\
\hline Maranhão (MA) & 18 & 966 & 75 & 33 & 380,742 & 985,136 \\
\hline Piauí (PI) & 8 & 17 & 317 & 85 & 217,931 & 456,811 \\
\hline Ceará (CE) & 251 & 1,779 & 47 & 179 & 572,730 & 1089,813 \\
\hline Rio Grando do Norte (RN) & 3 & 9 & 260 & 217 & 190,116 & 362,805 \\
\hline Paraíba (PB) & 31 & 148 & 8 & 70 & 273,135 & 524,967 \\
\hline Pernambuco (PE) & 1 & 17 & 617 & 1,029 & 518,956 & 1150,879 \\
\hline Alagoas (AL) & 52 & 390 & 161 & 138 & 214,726 & 439,655 \\
\hline Sergipe (SE) & 26 & 154 & 236 & 373 & 113,147 & 281,231 \\
\hline Bahia (BA) & 42 & 751 & 701 & 340 & 838,963 & 1808,376 \\
\hline Minas Gerais (MG) & 91 & 191 & 1286 & 347 & 756,335 & 1143,020 \\
\hline Espírito Santo (ES) & 2 & 3 & 222 & 25 & 120,911 & 190,049 \\
\hline Rio de Janeiro (RJ) & 24 & 190 & 1,130 & 189 & 196,330 & 827,847 \\
\hline São Paulo (SP) & 42 & 109 & 283 & 182 & 657,099 & 1327,024 \\
\hline Paraná (PR) & 25 & 50 & 46 & 48 & 308,754 & 406,918 \\
\hline Santa Catarina (SC) & 32 & 64 & 226 & 80 & 101,247 & 137,970 \\
\hline Rio Grande o Sul (RS) & 43 & 132 & 582 & 268 & 290,660 & 434,715 \\
\hline Mato Grosso do Sul (MS) & 108 & 332 & 614 & 485 & 32,588 & 145,224 \\
\hline Mato Grosso (MT) & 26 & 43 & 453 & 305 & 82,116 & 186,272 \\
\hline Goiás (GO) & 30 & 232 & 879 & 514 & 135,758 & 336,606 \\
\hline Destrito Federal (DF) & 33 & 89 & 302 & 100 & 41,943 & 86,524 \\
\hline
\end{tabular}

Source: Prepared using data from PNADs.

Note: LI2007 and LI2014 denote the number of Labor Inspections conducted in 2007 and 2014, respectively; Children2007 and Children2014 denote the number of child laborers withdrawn from work during Labor Inspections in 2007 and 2014, respectively; PBF2004 and PBF2014 denote the number of beneficiaries of the PBF in 2004 and 2014, respectively. 